PRACE GEOGRAFICZNE

zeszyt $151,2017,53-74$

doi: 10.4467/20833113PG.17.022.8034

Instytut Geografii i Gospodarki Przestrzennej UJ

Wydawnictwo Uniwersytetu Jagiellońskiego

\title{
VARIABILITY OF PRECIPITATION AND RUNOFF IN THE ENTIRE HIGH TATRA MOUNTAINS IN THE PERIOD 1961-2010
}

\author{
Marek Górnik, Ladislav Holko, \\ Joanna Pociask-Karteczka, Svetlana Bičárová
}

\begin{abstract}
The High Tatra Mountains are the highest mountain chain of alpine landforms in Central Europe to the east of the Alps. The northern (windward) part of the mountains is mostly located in Poland while the southern (leeward) part is in Slovakia. The article presents the first analysis of daily precipitation (10 stations) and discharge (7 catchments) data covering the entire territory of the mountains. Data from the period 1961-2010 were used in the analysis. The precipitation data confirmed significant differences between the windward and the leeward sides. We found an increase in the number of days with precipitation amounts 40 to $60 \mathrm{~mm}$ in the season from May to October in the decade 2001-2010 compared to previous decades. More frequent long wet periods in the decades 1991-2000 and 2001-2010 were found as well. Runoff from the catchments located on the windward side of the mountains is higher than on the leeward side. It reflects higher precipitation on the windward side, but also a higher mean elevation of the catchments. The statistical analysis revealed inhomogeneities in 5 of 7 runoff data series. An increase in the number of events classified as small and large floods found in several catchments on both sides of the mountains in the decade 2001-2010 can be attributed to the increase of the number of days with daily precipitation $40-60 \mathrm{~mm}$ and a higher frequency of the long-term wet periods.
\end{abstract}

Keywords: mountain hydrology, precipitation, river catchment, runoff, Carpathians, East-Central Europe

\section{Introduction}

High mountains represent a set of fragile ecosystems characterized by vertically differentiated climatic conditions, abundance of water and rich biodiversity. They provide a wide range of ecosystem services in forestry, agriculture, water supply, 
tourism, recreation, etc. (e.g. Fleischer et al. 2017). The awareness of the vulnerability of high mountains to a changing climate and increases in frequency and the intensity of extreme weather situations creates a need for a better understanding of the high mountain hydrologic system functioning (Huber et al. 2005). River runoff in mountainous catchments is extremely sensitive to climate change (Barnett et al. 2005). The search for trends (or lack thereof) in river discharge data series has become an object of scientific interest with practical importance in the last decades. The results are essential for planning water supply and flood-protection systems, where system design has been traditionally based on the assumption of stationarity of river flow (Ruiz-Villanueva et al. 2016). Precipitation and air temperature are considered to be the principal drivers of hydrologic changes.

The Tatra Mountains are the highest mountains of Central Europe to the east from the Alps. They form part of the European water divide between the Baltic Sea and the Black Sea and part of the border between Slovakia and Poland. The highest part of the Tatra Mountains is called the High Tatra Mountains. Because the mountains significantly influence hydrological cycle in this part of Europe, a number of studies related to changes in meteorological and hydrological phenomena was conducted in the last decade. The study of extreme meteorological phenomena by Ustrnul and Czekierda (2009) documented the occurrence of the heaviest rainfalls in southern mountainous part of Poland. Annual precipitation maximum in this part of Europe occurs in summer (Niedźwiedź 2003). Climate in the northern mountainous part of Slovakia become more humid and upward shifts of climatic zones were registered in the Slovak Tatra Mountains in the 20th and at the beginning of the 21st century (Melo et al. 2013).

Numerous studies reported the increase in air temperature in the Tatra Mountains. Bokwa et al. (2013) and Łupikasza et al. (2016) concluded that the annual air temperature was increasing by $0.14^{\circ} \mathrm{C}$ per decade in the Polish Tatra Mountains in the period 1951-2006 whereas no significant trend was found in mean annual precipitation. March and September were the only months with precipitation increase while in August the decreasing precipitation trend was found. The air temperature has been increasing in spring and summer since the beginning of the 1980s and in autumn since the beginning of the 1990s. Vivid fluctuations with no clear trends were typical for winter air temperature. Pribullová et al. (2013) found statistically significant linear increase in annual air temperature in the Slovak Tatra Mountains in the period $1961-2007\left(0.21-0.30^{\circ} \mathrm{C}\right.$ per decade). Their analysis of monthly temperature time series showed the most rapid increase in summer and winter months, i.e. in July, August, December and January. The increasing trends were found also for maximum and minimum daily air temperatures.

The long-term series of annual precipitation totals showed slight decrease during the period 1881-2009, likewise winter, spring and autumn precipitation totals, 
whereas the increasing precipitation was found for summer in Slovak part of the Carpathians. The upward trends have been found also for maximum and minimum daily air temperature. In the period 1980-2009 the upward shift of climatic zones was noticed in the Slovak Tatra Mts (Melo et al. 2013). Bičárová and Holko (2013) reported a significant increase in the number of days with daily precipitation $40-60 \mathrm{~mm}$ and increased precipitation at higher elevations in the Slovak High Tatra Mountains in the period 1961-2010. They suggested that the increase may be related to a more frequent occurrence of the long term wet periods during the last two decades. A significant increase of discharges classified as small flood events they found for some catchments in the decade 2001-2010 was attributed to that increased precipitation.

Analysis of daily river discharges (1928-2008) of the Belá river draining part of the Slovak Tatra Mountains conducted by Halmová and Pekárová (2011) did not show any important changes in the number of extreme floods and the temporal extent of droughts. On the other hand, recent research of flood trends in two headwater catchments in the Polish part of the Tatra Mountains revealed positive trends of the annual maximum discharge in the last four decades (Ruiz-Villanueva et al. 2016).

Hydrological individuality of particular catchments was observed (PociaskKarteczka et al. 2010). Holko et al. (2001) also reported big differences in hydrological balance of neighbouring catchments which were attributed to inadequate precipitation network. Kasina et al. (2006-2007) and Pociask-Karteczka et al. (2010) found that flood events were not uniformly distributed in time and space in the Polish Tatra Mountains. It was attributed to complex meteorological conditions in mountainous areas, where flood-inducing precipitation depends more on local air circulation than on macro-scale circulation. Moreover, the research of Pociask-Karteczka et al. (2010) revealed a "clustering" of flood events during periods of several consequent years interrupted by years without flood events.

The results of contemporary European research show that there has been no ubiquitous increase or decrease in river runoff in Europe (Blöschl, Montanari 2010; Mudelsee et al. 2003). National studies analysing long-time series of high river flow records in Europe did not show uniform increasing/decreasing trends at a regional scale (Kundzewicz 2012). Similar conclusions were reported in earlier research conducted at various scales in Europe. For example, an examination of a worldwide set of 199 long-time series of annual values of maximum daily discharges comprising 70 series from European rivers showed that only 20 of them exhibited statistically significant changes (Kundzewicz et al. 2004, 2005). However, Parajka et al. (2010) found a distinct shift in flood generating processes in the Alpine-Carpathian range from summer to autumn floods.

The above review reveals that there is no general tendency in river runoff in the Tatra Mountains. Different length of data sets, and different methods do not allow 
comparative analysis for the entire mountain region. The research presented in this paper tries to fill this gap by analyzing long-term changes and spatial distribution of precipitation and streamflow in mountain catchments of both Polish and Slovak High Tatra Mountains in the same period and using the same methods.

\section{Study area and data}

The High Tatra Mountains are the only part of the Carpathian Mountains featuring larger scale rocky high Alpine landscape. The area of the mountains is $341 \mathrm{~km}^{2}\left(260 \mathrm{~km}^{2}\right.$ in Slovakia, $81 \mathrm{~km}^{2}$ in Poland). Although the main ridge is only $26 \mathrm{~km}$ long and the width of the mountains is just $17 \mathrm{~km}$, they are the "water towers" of both countries owing to the steep vertical gradient $(1800 \mathrm{~m})$ between the mountain crest and the foothills. The mountains were formed by the Alpine orogeny. The present relief was significantly influenced by the Pleistocene glaciation leaving the U-shaped valleys, series of cirque basins and knife-edged arêtes (Lukniš 1973). Altitudinal geoecological belts range from the deciduous forest at the foothills, the timberline at higher elevations to alpine meadows and the uppermost periglacial belt of rock faces, frost-shattered debris and locally permanent snow patches (Kotarba 1992). The temperate climate in transitional position is influenced by oceanic and continental air masses. The mountains give birth to significant tributaries of the Vistula and Danube rivers. The discharge of the streams exhibits a pronounced seasonal peak resulting from spring snowmelt enhanced and prolonged by summer rainfalls. Almost $80 \%$ of runoff occurs in May to October. The streams have pluvio-nival or nivo-pluvial patterns of flow regime. The mean multiannual specific runoff amounts from 40 to $50 \mathrm{l} \cdot \mathrm{s}^{-1} \cdot \mathrm{km}^{-2}$. The variability of daily runoff during a year is considerable (Pociask-Karteczka et al. 2010).

\section{Data}

Daily precipitation data from ten meteorological stations and daily runoff from seven catchments located in Poland (northern slopes of the High Tatra Mountains) and Slovakia (southern slopes) were analysed (Fig. 1). All precipitation and hydrological stations are part of the national monitoring networks of the Slovak Hydrometeorological Institute (SHMI) and the Institute of Meteorology and Water Management National Research Institute (IMGW-PIB). The altitude of precipitation stations spans between 694 and $2635 \mathrm{~m}$ a.s.l. (Tab. 1, col. 5). With one exception, the area of the catchments does not exceed $100 \mathrm{~km}^{2}$ (Tab. 2, col. 3). All streams draining the studied catchments eventually flow to the Vistula River (the Baltic Sea basin). 
Lengths of individual precipitation and runoff data series differ since the regular observations started in different years and sometimes finished due to technical or other reasons. The daily precipitation from the years 1961 (or 1968) to 2010 and the daily discharges from the hydrological years 1963-2010 were chosen for the analyses. The hydrological year in both countries starts on November 1st and ends on October 31st.

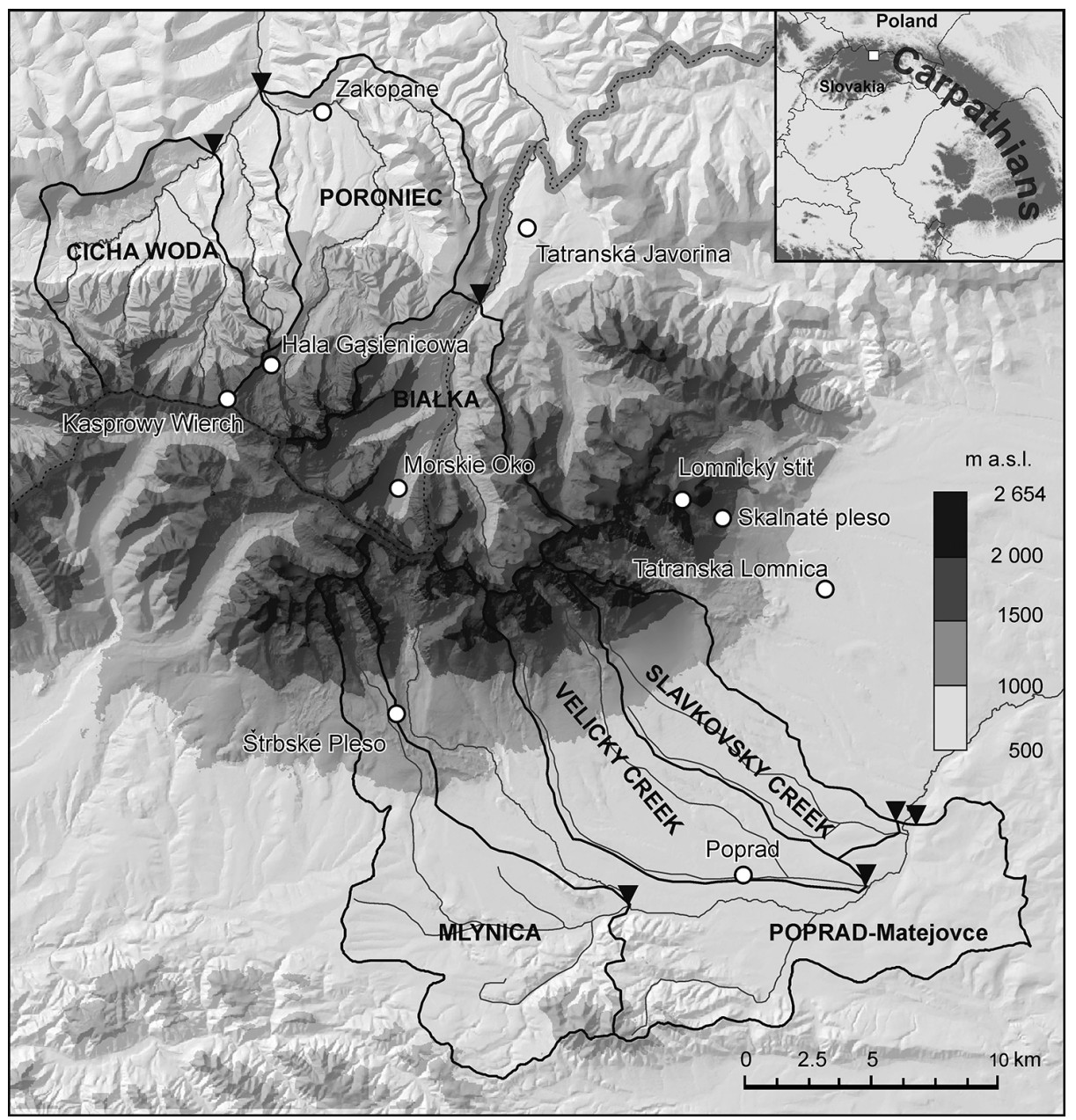

Fig. 1. Location of the study area, precipitation stations (circles) and water divides of the catchments

Source: https://dds.cr.usgs.gov/srtm/version2_1/SRTM3/Eurasia/, http://polski.mapywig.org 
Table 1. Precipitation stations; $\mathrm{P}$ is the mean annual precipitation

\begin{tabular}{|c|c|c|c|c|c|c|}
\hline Location & Symbol & Latitude & Longitude & $\begin{array}{l}\text { Altitude } \\
\text { [m a.s.l.] }\end{array}$ & $\begin{array}{c}P \\
{[\mathrm{~mm}]}\end{array}$ & Data set \\
\hline 1 & 2 & 3 & 4 & 5 & 6 & 7 \\
\hline Lomnický štít & LS & 49॰12'00" N & $20^{\circ} 13^{\prime} 00^{\prime \prime} \mathrm{E}$ & 2635 & 1496 & 1961-2010 \\
\hline Kasprowy Wierch & KW & 49॰13'57" N & 19॰58' $55^{\prime \prime} \mathrm{E}$ & 1991 & 1809 & $1961-2010$ \\
\hline Skalnaté Pleso & SkP & $49^{\circ} 11^{\prime} 22^{\prime \prime} \mathrm{N}$ & $20^{\circ} 14^{\prime} 03^{\prime \prime} \mathrm{E}$ & 1778 & 1345 & $1961-2010$ \\
\hline Hala Gąsienicowa & $H G$ & 49॰14' 39” N & $20^{\circ} 00^{\prime} 21^{\prime \prime} \mathrm{E}$ & 1520 & 1716 & 1968-2010 \\
\hline Morskie Oko & MO & 49॰12'00" N & $20^{\circ} 05^{\prime} 00^{\prime \prime} \mathrm{E}$ & 1408 & 1576 & $1968-2010$ \\
\hline Štrbské Pleso & StP & 49॰07'09” N & $20^{\circ} 03^{\prime} 26^{\prime \prime} \mathrm{E}$ & 1354 & 1025 & $1961-2010$ \\
\hline Tatranská Javorina & TJ & 49॰15’02” N & $20^{\circ} 09^{\prime} 29^{\prime \prime} \mathrm{E}$ & 1030 & 1303 & $1961-2010$ \\
\hline Zakopane & $Z A$ & 49॰18'00" N & $19 \circ 57 ’ 59 " \mathrm{E}$ & 855 & 1140 & $1961-2010$ \\
\hline Tatranská Lomnica & $\mathrm{TL}$ & $49^{\circ} 09^{\prime} 46^{\prime \prime} \mathrm{N}$ & $20^{\circ} 17^{\prime} 17^{\prime \prime} \mathrm{E}$ & 827 & 794 & $1961-2010$ \\
\hline Poprad & PP & 49॰04'06" N & $20^{\circ} 15^{\prime} 58^{\prime \prime} \mathrm{E}$ & 694 & 598 & $1961-2010$ \\
\hline
\end{tabular}

Source: LS, SkP, StP, TJ, TL, PP after Bičárová, Holko 2013; other stations - completed by authors.

Table 2. Basic characteristics of the catchments

\begin{tabular}{|l|c|c|c|c|c|}
\hline \multicolumn{1}{|c|}{ River - water level gauge } & Symbol & $\begin{array}{c}\text { Area } \\
{\left[\mathrm{km}^{2}\right]}\end{array}$ & $\begin{array}{c}\text { Mean altitude } \\
{[\mathrm{m} \text { a.s.I. }}\end{array}$ & $\begin{array}{c}\text { Mean annual } \\
\text { runoff } \\
{[\mathrm{mm}]}\end{array}$ & Data set \\
\hline Białka - Łysa Polana & 2 & 3 & 4 & 5 & 6 \\
\hline Poroniec - Poronin & B- & 63 & 1791 & 1585 & $1963-2010$ \\
\hline Cicha Woda - Zakopane & C-Z & 58 & 1110 & 664 & $1966-2010$ \\
\hline Mlynica - Svit & M-S & 83 & 991 & 219 & $1963-2010$ \\
\hline Velický creek - Velká & V-V & 58 & 1094 & 505 & $1963-2010$ \\
\hline Slavkovský creek - Matejovce & S-M & 43 & 1017 & 358 & $1963-2010$ \\
\hline Poprad - Matejovce & P-M & 315 & 1018 & 399 & $1963-2009$ \\
\hline
\end{tabular}

Source: M-S, V-V, S-M, P-M after Bičárová, Holko 2013; other catchments - completed by authors.

\section{Methods}

First, the homogeneity of the data series was tested. The homogeneity of precipitation data was tested by the SNHT test (Alexandersson 1986) and the Bivariate test (Maronna, Yohai 1978) using the ProClimDB software (Štěpánek 2010). The homogeneity of runoff data series was tested by the von Neumann test, because the data did not have normal distribution required for the SNHT test. Precipitation and runoff values on the northern (windward) and southern (leeward) slopes of the High Tatra Mountains were compared. Statistical parameters based on frequency 
distribution such as 1st and 3rd quartiles (q1, q3), median, mean, 95th and 99th percentiles ( $\mathrm{p} 95, \mathrm{p} 99)$ were calculated to characterize temporal variability of daily precipitation $(\mathrm{mm})$ and daily discharge $\left(\mathrm{m}^{3} \cdot \mathrm{s}^{-1}\right)$. Frequencies of successive periods without precipitation (dry periods) and with precipitation (wet periods) were calculated. Temporal evolution of the wet and dry periods was evaluated for particular decades. Categories of dry and wet periods were distinguished as follows:

- short-term wet/dry period (ST) with duration in the range between 1 and 5 days,

- middle-term wet/dry period (MT) with duration in the range between 6 and 10 days,

- long-term wet/dry period (LT) with duration more than 10 days.

The classification of the Integrated Warning Service System (IWSS) by the Czech Hydrometeorological Institute (http://pocasi.chmi.cz/en/) was used for the evaluation of the number of days with potentially dangerous rainfall. The IWSS criteria assess the risk of damages in human society including i.a. disruption of settlements and transport infrastructure, erosion of soil, contamination of surface and groundwater, increased risk of injuries and infectious (public health) and fatalities. Data the from warm half-year (May to October) were analysed, because solid precipitation prevails in the High Tatra Mountains in the rest of the year. Three degrees of risk were determined:

- low risk - daily precipitation between 40 and $60 \mathrm{~mm}$ (potentially dangerous situation);

- high risk - daily precipitation from 60 to $90 \mathrm{~mm}$ (potential of material damage on large area);

- extreme risk - daily precipitation above $90 \mathrm{~mm}$ (potential of enormous material damage and hazard to human life).

Daily discharge data were analysed for each catchment to obtain duration (number of days) of extremely low flows and flows defined as small and high floods by the Indicators of Hydrologic Alteration (IHA) software (The Nature Conservancy 2009). The extreme low flow was defined as flow less than or equal to the 10th percentile of daily river discharges. The small flood represented flow event with river discharge exceeding the 75th percentile of the daily river discharge and the return interval of the peak flow greater than 2 years. The high flood was defined as flow event that had river discharge exceeding the 75 th percentile of the daily river discharge and the return interval of the peak flow greater than 10 years.

\section{Results - Precipitation}

Detection of homogeneity was performed for monthly, seasonal and annual precipitation totals. The test found great inhomogeneity at station Lomnický štít in 1991. The inhomogeneity was corrected with the help of reference series from the neighboring stations (SkP, TL, PP, StP, TJ). After the correction, correlation between 
homogenized values of annual precipitation for the Lomnický štít mountain and reference series slightly increased $(+0.044)$. The increase was bigger for the winter $(+0.100)$ than for the summer $(+0.008)$ periods (Mačutek et al. 2011).

The difference between the precipitation totals at the lowest and high elevations exceeds $1200 \mathrm{~mm}$ (Tab. 1, col. 6). The lowest mean annual precipitation (598 mm) occurs at the station Poprad (694 m a.s.l., valley position on the leeward side of the mountains) and the highest one (1809 mm) at Kasprowy Wierch (1991 m a.s.l.) representing the high elevation windward position. There are considerable differences in annual precipitation at the same elevation on the leeward and windward slopes of the High Tatra Mountains (Fig. 2). Elevation gradients of mean annual precipitation differ as well. They reach $46 \mathrm{~mm}$ and $60 \mathrm{~mm}$ per $100 \mathrm{~m}$ for the leeward and windward slopes, respectively (Fig. 2). The differences between the leeward and windward locations are well shown by comparing stations located approximately at the same altitude. Mean annual precipitation in Zakopane (windward side) in hydrological years 1961-2010 was $1140 \mathrm{~mm}$ while in Tatranská Lomnica (the leeward side) it was only $794 \mathrm{~mm}$. The difference seems to increase with elevation - mean annual precipitation at Morskie Oko (windward side) in the years 1968-2010 was $1575 \mathrm{~mm}$, at Štrbské Pleso (leeward side) it was $1023 \mathrm{~mm}$. The shading effect of the High Tatra Mountains seems to be visible also in Poprad which has less precipitation than some stations located at a similar altitude in the nearby Liptov valley in Slovakia (Liptovský Hrádok, Liptovský Mikuláš).

Statistical characteristics of daily precipitation are given in Tab. 3 and Fig. 3. Precipitation at the lowest altitude on the southern slope (PP) has the smallest range. The highest ranges and the highest number of outliers have been observed on the windward side of the High Tatra Mountains (KW, HG, MO). The mean values of daily precipitation do not vary significantly among the stations located on the windward slope and reach values from 7.7 to $7.9 \mathrm{~mm}$; mean daily precipitation ranges from 3.9 to $6.9 \mathrm{~mm}$ on the leeward slope. Median values $(3.4$ to $4.0 \mathrm{~mm})$ are lower than the means (1.6 to $4.1 \mathrm{~mm}$ ). One quarter (the 1 st quartile) of daily precipitation does not exceed $1 \mathrm{~mm}$ at five stations and four of them are located on the leeward slope of the High Tatra Mountains. The value of the 1st quartile at the stations situated on the northern slopes ranges from 1 to 1.4 (Tab. 3, col. 4).

Maximum daily precipitation ranges from $79 \mathrm{~mm}$ (PP) to $300 \mathrm{~mm}$ (HG) and at stations situated on the northern slope it is considerably higher than at stations located on the southern slope of the studied territory. Absolute daily maxima $232 \mathrm{~mm}$ and $300 \mathrm{~mm}$ recorded at the Kasprowy Wierch mountain and the nearby station Hala Gąsienicowa, respectively, in June 1973 represent the highest recorded daily precipitation in Poland. Much lower daily precipitation (between 79 and $147 \mathrm{~mm}$ ) occurred on the same day in the Slovak High Tatra Mountains. This is consistent with the results published by Cebulak et al. (2000) and Faško et al. (2000) who analysed extreme 


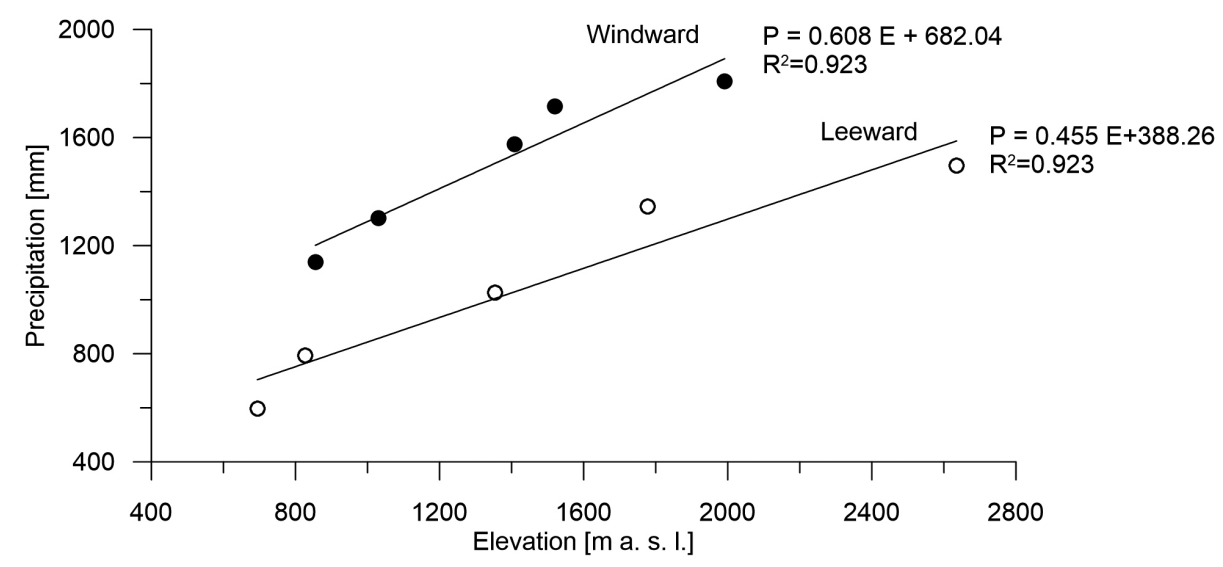

Fig. 2. Elevation gradients of the mean annual precipitation along the leeward (southern, circles) and windward (northern, dots) slopes of the High Tatra Mountains

Explanations: $\mathrm{P}$ - precipitation; E - elevation; $\mathrm{R}$ - linear correlation coefficient.

Source: author's own study based on data from Tab. 1.

Table 3. Summary statistics of daily precipitation (dP) at the stations in the High Tatra Mountains in the years 1961-2010 (LS, KW, SkP, StP, TJ, ZA, TL, PP) and 1968-2010 (MO, HG)

\begin{tabular}{|c|c|c|c|c|c|c|c|c|c|}
\hline Site & $\begin{array}{c}\text { Altitude } \\
\text { [m a.s.I.] }\end{array}$ & $\begin{array}{c}\mathrm{dP}>0 \mathrm{~mm} \\
\text { rel. freq. [\%] }\end{array}$ & $\mathrm{q} 1$ & Median & Mean & $\mathrm{q} 3$ & $95 \mathrm{p}$ & $99 \mathrm{p}$ & Maximum \\
\hline 1 & 2 & 3 & 4 & 5 & 6 & 7 & 8 & 9 & 10 \\
\hline LS & 2635 & 59 & 1.4 & 4.1 & 6.9 & 9.3 & 23.5 & 41.2 & 92.0 \\
\hline KW & 1991 & 63 & 1.3 & 4.0 & 7.9 & 10.1 & 23.3 & 56.2 & 232.0 \\
\hline SkP & 1778 & 56 & 0.8 & 3.1 & 6.5 & 8.3 & 24.8 & 43.7 & 145.0 \\
\hline HG & 1520 & 61 & 1.0 & 3.4 & 7.8 & 9.8 & 29.2 & 63.7 & 300.0 \\
\hline M0 & 1408 & 56 & 1.4 & 3.9 & 7.7 & 9.8 & 28.0 & 51.4 & 164.0 \\
\hline StP & 1354 & 57 & 0.7 & 2.4 & 4.9 & 6.4 & 17.9 & 30.9 & 101.0 \\
\hline TJ & 1030 & 52 & 1.2 & 3.5 & 6.9 & 8.7 & 24.4 & 50.0 & 147.0 \\
\hline ZA & 857 & 54 & 0.7 & 2.5 & 5.7 & 7.1 & 21.6 & 44.2 & 138.7 \\
\hline TL & 855 & 46 & 0.8 & 2.4 & 4.7 & 6.0 & 17.3 & 30.4 & 83.0 \\
\hline PP & 827 & 42 & 0.5 & 1.6 & 3.9 & 4.8 & 15.6 & 28.4 & 79.0 \\
\hline
\end{tabular}

Source: LS, SkP, StP, TJ, TL, PP after Bičárová, Holko 2013; other sites - completed by authors. 


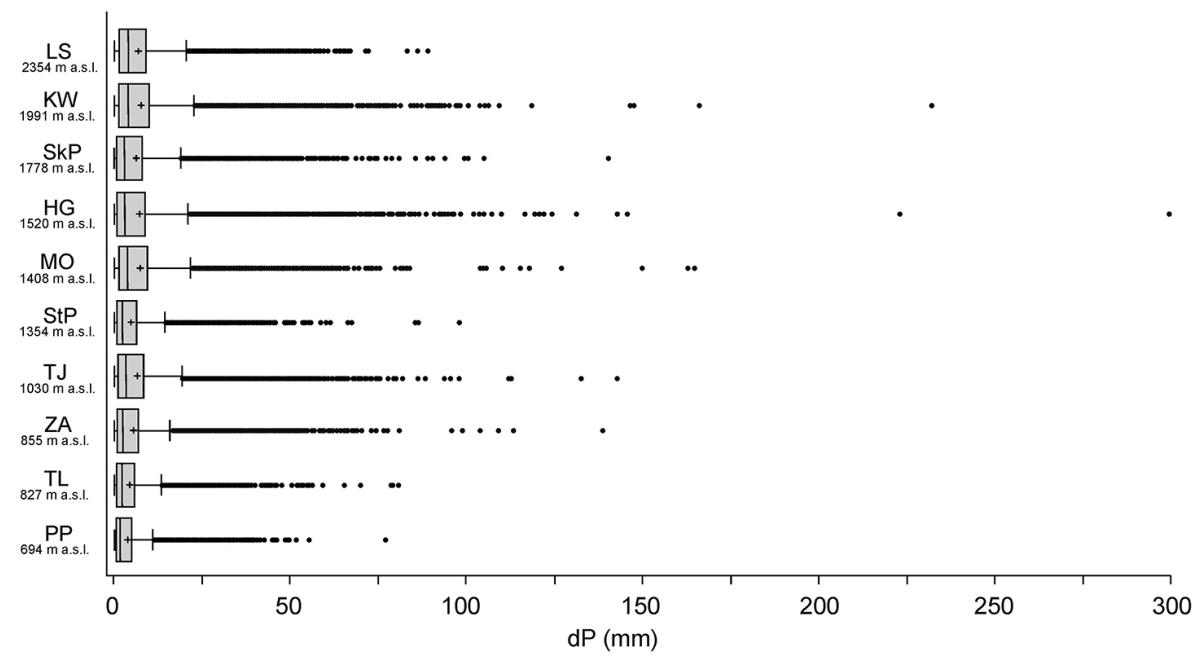

Fig. 3. Box-Whisker plot of daily precipitation in the years 1961-2010 (LS, KW, SkP, StP, TJ, ZA, TL, PP) and 1968-2010 (MO, HG); the statistics from the left to the right represent QL-1.5.IRQ (the left whisker), 25\% quantile, median, mean (the plus sign), 75\% quantile, QU+1.5.IRQ (the right whisker); outliers (circles) are the points that fall below QL-1.5.IRQ or above QU+1.5.IRQ, where IRQ is the interquartile range (the difference between the first and the third quartiles), QL and QU are values of the lower and upper quartiles, respectively Source: LS, SkP, StP, TJ, TL, PP after Bičárová, Holko 2013; other stations - completed by authors.

precipitation events and daily precipitation maxima in the Western Carpathians and Slovakia, respectively. Both concluded that events with precipitation equal or higher than $100 \mathrm{~mm}$ in the studied regions are rare, and that they are typical for the High Tatra Mountains.

The relative frequency of days with precipitation $>0 \mathrm{~mm}$ varies from $42 \%$ (PP) to $63 \%(\mathrm{KW})$. The highest values of the relative frequency $(56 \%-63 \%)$ are characteristic for stations above $1400 \mathrm{~m}$ a.s.l. (Tab. 3, col. 2, 3). The "wettest" station is HG: quantile $99 \mathrm{p}$ reaches value $63.7 \mathrm{~mm}$, while at the PP it has the value of only $28.4 \mathrm{~mm}$ (Tab. 3, col. 9).

\section{Dry and wet periods}

The total number of dry and wet periods varies between 498 and 602 per decade. The values for individual periods and precipitation stations are similar (Tab. 4, col. 6,12$)$. The longest period without precipitation that lasted 75 days (1991-2000) 
was observed at the station MO. This value is extreme among the values from other periods and stations. The second longest dry period was observed at the station PP in the decade 1961-1970 and it was 36 days long.

Wet periods lasting more than 30 days occurred at stations LS (1981-1990, 1991-2000), KW (1991-2000, 2000-2010), HG (1991-2000) and interestingly also at lower elevation at TJ (1961-1971); Tab. 4, col. 13). The sum of precipitation in particular decades indicates a pronounced increase of precipitation in the decade 2001-2010 (Tab. 4, col. 8). There are less long-term dry periods in the decades 1991-2000 and 2001-2010 at all stations and more long-lasting wet periods in the decade 2001-2010 on the windward slope of the High Tatra Mountains (Tab. 4, col. $5,11)$. Middle-term and long-term periods suggest a more a frequent occurrence of wet periods at stations located above $1000 \mathrm{~m}$ a.s.l. (LS, KW, SkP, HG, MO, StP; Tab. 4, col. 10, 11). TL and PP had extremely low number of the long-term wet periods (Tab. 4, col. 11). A substantial increase of decadal precipitation during the last decade (2001-2010) was observed at these stations. Non-pronounced changes were found for the short-term dry and wet periods (Tab. 4, col. 3, 9).

\section{Changes of precipitation in the warm season of a year}

Precipitation in the warm season of the year (May to October) enhances snowmelt floods and influences summer rain floods. The relative frequency of daily precipitation ranging from 40 to $60 \mathrm{~mm}$ is considerably higher on the windward slope of the High Tatra Mountains (KW, HG, MO) and exceeds 20 or 30 days in nearly all decades (Fig. 4). There is a significant increase in the number of days with potentially dangerous precipitation (40 to $60 \mathrm{~mm}$ per day) at all stations except HG. A frequent occurrence of daily precipitation totals of $60-90 \mathrm{~mm}$ in the decade $2001-2010$ is noticeable at stations HG, KW, TJ, LS. A significantly more frequent occurrence of potentially the most dangerous daily precipitation $>90 \mathrm{~mm}$ during the same decade in comparison to the decades 1981-1990 and 1991-2000 has been observed at HG, KW, MO, TJ. Interestingly, such precipitation did not occur at all at the highest station at Lomnický štít in 2001-2010 and in 1961-1990, and at TJ in 1971-1990.

\section{Results - Streamflow}

The mean annual catchment runoff in the catchments varied between 219 and $1585 \mathrm{~mm}$ (Tab. 2). Runoff from the catchments located on the windward slopes of the High Tatra Mountains is higher than from the catchments located on the leeward slopes. However, unlike with precipitation stations located at the same elevation, analogical comparison is not possible for catchment runoff. Each catchment has unique physical-geographic characteristics. Higher mean elevation of the catchments 
Table 4. Characteristics of dry and wet periods at the precipitation stations in the High Tatra Mountains; ST, LT and LT are short-term, middle-term and long-term periods as defined in the methodology

\begin{tabular}{|c|c|c|c|c|c|c|c|c|c|c|c|c|}
\hline \multirow[b]{2}{*}{ Site } & \multirow[b]{2}{*}{ Decade } & \multicolumn{5}{|c|}{ Number of dry periods } & \multirow[b]{2}{*}{$\begin{array}{l}\text { Sum of pre- } \\
\text { cipitation } \\
\text { [mm/deca- } \\
\text { de] }\end{array}$} & \multicolumn{5}{|c|}{ Number of wet periods } \\
\hline & & ST & MT & LT & Total & $\begin{array}{l}\text { Duration } \\
\text { of the } \\
\text { longest } \\
\text { period in } \\
\text { days }\end{array}$ & & ST & MT & LT & Total & $\begin{array}{c}\text { Duration } \\
\text { of the } \\
\text { longest } \\
\text { period in } \\
\text { days }\end{array}$ \\
\hline 1 & 2 & 3 & 4 & 5 & 6 & 7 & 8 & 9 & 10 & 11 & 12 & 13 \\
\hline \multirow{5}{*}{ LS } & 1961-1970 & 546 & 43 & 11 & 600 & 24 & 16475 & 505 & 74 & 22 & 601 & 25 \\
\hline & $1971-1980$ & 500 & 50 & 17 & 567 & 20 & 14756 & 460 & 83 & 23 & 566 & 22 \\
\hline & 1981-1990 & 504 & 47 & 8 & 559 & 21 & 14742 & 431 & 106 & 22 & 559 & 31 \\
\hline & 1991-2000 & 498 & 53 & 3 & 554 & 13 & 17763 & 422 & 94 & 39 & 555 & 34 \\
\hline & 2001-2010 & 513 & 38 & 8 & 559 & 13 & 19908 & 434 & 81 & 43 & 558 & 25 \\
\hline \multirow{5}{*}{ KW } & 1961-1970 & 503 & 39 & 6 & 548 & 21 & 18532 & 416 & 94 & 39 & 549 & 25 \\
\hline & $1971-1980$ & 473 & 39 & 10 & 522 & 19 & 19057 & 378 & 106 & 37 & 521 & 22 \\
\hline & 1981-1990 & 535 & 34 & 9 & 578 & 18 & 17134 & 444 & 106 & 28 & 578 & 27 \\
\hline & $1991-2000$ & 495 & 41 & 2 & 538 & 13 & 17842 & 401 & 94 & 43 & 538 & 33 \\
\hline & $2001-2010$ & 502 & 39 & 9 & 550 & 16 & 17905 & 430 & 78 & 43 & 551 & 32 \\
\hline \multirow{5}{*}{ SkP } & 1961-1970 & 532 & 55 & 15 & 602 & 21 & 13024 & 515 & 72 & 12 & 602 & 16 \\
\hline & 1971-1980 & 500 & 44 & 16 & 560 & 25 & 12753 & 438 & 98 & 24 & 560 & 19 \\
\hline & 1981-1990 & 529 & 51 & 13 & 593 & 23 & 12526 & 477 & 102 & 14 & 593 & 24 \\
\hline & $1991-2000$ & 525 & 50 & 5 & 580 & 19 & 13748 & 464 & 83 & 34 & 581 & 23 \\
\hline & 2001-2010 & 522 & 51 & 12 & 585 & 17 & 15194 & 472 & 83 & 29 & 584 & 24 \\
\hline \multirow{4}{*}{$H G$} & 1971-1980 & 471 & 40 & 16 & 527 & 19 & 17425 & 390 & 105 & 32 & 527 & 24 \\
\hline & 1981-1990 & 507 & 42 & 10 & 559 & 18 & 16177 & 426 & 104 & 29 & 559 & 25 \\
\hline & $1991-2000$ & 492 & 47 & 5 & 544 & 15 & 16828 & 413 & 94 & 37 & 544 & 33 \\
\hline & 2001-2010 & 489 & 45 & 8 & 542 & 16 & 18322 & 417 & 83 & 43 & 543 & 27 \\
\hline \multirow{4}{*}{ MO } & 1971-1980 & 448 & 39 & 11 & 498 & 19 & 17288 & 340 & 114 & 44 & 498 & 24 \\
\hline & 1981-1990 & 501 & 55 & 16 & 572 & 47 & 14108 & 472 & 79 & 22 & 573 & 22 \\
\hline & $1991-2000$ & 462 & 76 & 19 & 557 & 75 & 14294 & 471 & 67 & 18 & 556 & 27 \\
\hline & 2001-2010 & 497 & 53 & 9 & 559 & 16 & 17096 & 446 & 71 & 43 & 560 & 24 \\
\hline \multirow{5}{*}{ StP } & 1961-1970 & 527 & 51 & 7 & 585 & 21 & 9898 & 474 & 84 & 27 & 585 & 23 \\
\hline & $1971-1980$ & 488 & 41 & 15 & 544 & 26 & 9808 & 409 & 111 & 24 & 544 & 20 \\
\hline & 1981-1990 & 509 & 56 & 17 & 582 & 17 & 9094 & 475 & 88 & 19 & 582 & 21 \\
\hline & $1991-2000$ & 508 & 62 & 5 & 575 & 18 & 10878 & 470 & 73 & 33 & 576 & 26 \\
\hline & 2001-2010 & 515 & 54 & 11 & 580 & 22 & 11583 & 466 & 83 & 30 & 579 & 25 \\
\hline
\end{tabular}


VARIABILITY OF PRECIPITATION AND RUNOFF IN THE ENTIRE HIGH TATRA MOUNTAINS ...65

\begin{tabular}{|c|c|c|c|c|c|c|c|c|c|c|c|c|}
\hline 1 & 2 & 3 & 4 & 5 & 6 & 7 & 8 & 9 & 10 & 11 & 12 & 13 \\
\hline \multirow{5}{*}{ TJ } & $1961-1970$ & 570 & 66 & 13 & 649 & 22 & 12161 & 583 & 53 & 12 & 648 & 31 \\
\hline & $1971-1980$ & 474 & 79 & 25 & 578 & 26 & 12364 & 508 & 55 & 15 & 578 & 20 \\
\hline & $1981-1990$ & 544 & 65 & 11 & 620 & 18 & 12341 & 526 & 79 & 15 & 620 & 22 \\
\hline & $1991-2000$ & 536 & 51 & 12 & 599 & 15 & 13507 & 502 & 80 & 18 & 600 & 25 \\
\hline & $2001-2010$ & 545 & 59 & 13 & 617 & 22 & 15127 & 528 & 70 & 18 & 616 & 25 \\
\hline \multirow{5}{*}{ ZA } & $1961-1970$ & 545 & 62 & 10 & 617 & 17 & 11469 & 531 & 66 & 21 & 618 & 15 \\
\hline & $1971-1980$ & 500 & 54 & 16 & 570 & 21 & 11615 & 450 & 101 & 18 & 569 & 17 \\
\hline & $1981-1990$ & 572 & 53 & 9 & 634 & 16 & 10710 & 543 & 78 & 14 & 635 & 22 \\
\hline & $1991-2000$ & 542 & 52 & 9 & 603 & 17 & 10939 & 503 & 76 & 23 & 602 & 27 \\
\hline & $2001-2010$ & 522 & 57 & 8 & 587 & 13 & 12259 & 488 & 75 & 25 & 588 & 27 \\
\hline \multirow{5}{*}{ TL } & $1961-1970$ & 535 & 66 & 26 & 627 & 23 & 7954 & 571 & 52 & 4 & 627 & 13 \\
\hline & $1971-1980$ & 509 & 70 & 28 & 607 & 34 & 8098 & 556 & 46 & 6 & 608 & 22 \\
\hline & $1981-1990$ & 485 & 97 & 25 & 607 & 22 & 7353 & 563 & 38 & 6 & 607 & 20 \\
\hline & $1991-2000$ & 550 & 74 & 15 & 639 & 22 & 7739 & 583 & 48 & 8 & 639 & 18 \\
\hline & $2001-2010$ & 531 & 70 & 19 & 620 & 29 & 8622 & 551 & 60 & 8 & 619 & 23 \\
\hline \multirow{5}{*}{ PP } & $1961-1970$ & 524 & 68 & 32 & 624 & 36 & 5933 & 585 & 38 & 2 & 625 & 9 \\
\hline & $1971-1980$ & 501 & 75 & 26 & 602 & 28 & 5956 & 550 & 46 & 5 & 601 & 16 \\
\hline & $1981-1990$ & 522 & 86 & 22 & 630 & 26 & 5484 & 590 & 37 & 4 & 631 & 13 \\
\hline & $1991-2000$ & 525 & 90 & 19 & 634 & 26 & 5832 & 592 & 41 & 1 & 634 & 11 \\
\hline & $2001-2010$ & 541 & 83 & 19 & 643 & 26 & 6706 & 602 & 37 & 3 & 642 & 19 \\
\hline
\end{tabular}

Source: LS, SkP, StP, TJ, TL, PP - after Bičárová, Holko, 2013; other sites - completed by authors.

located on the windward slopes can multiply the effect of higher precipitation revealed for these slopes (Fig. 5).

It should be noted that all runoff data series except Białka and Poroniec exhibited inhomogeneities. The data from the Mlynica, Velický creek and Poprad-Matejovce catchments were inhomogeneous in the first 7, 5 and 5 years, respectively. The data from the Slavkovský creek had inhomogeneities in the first 7 and last 5 years. Independent homogenous data from neighbouring catchments were not available. Therefore, the first seven years from the data series of Mlynica, Velický creek and Poprad-Matejovce were excluded and data from the Slavkovský creek were not used in further analyses at all. First ten years of data from Białka, Poroniec and Cicha Woda were excluded as well to obtain the data series of the same duration (1971-2010) for the comparisons. 

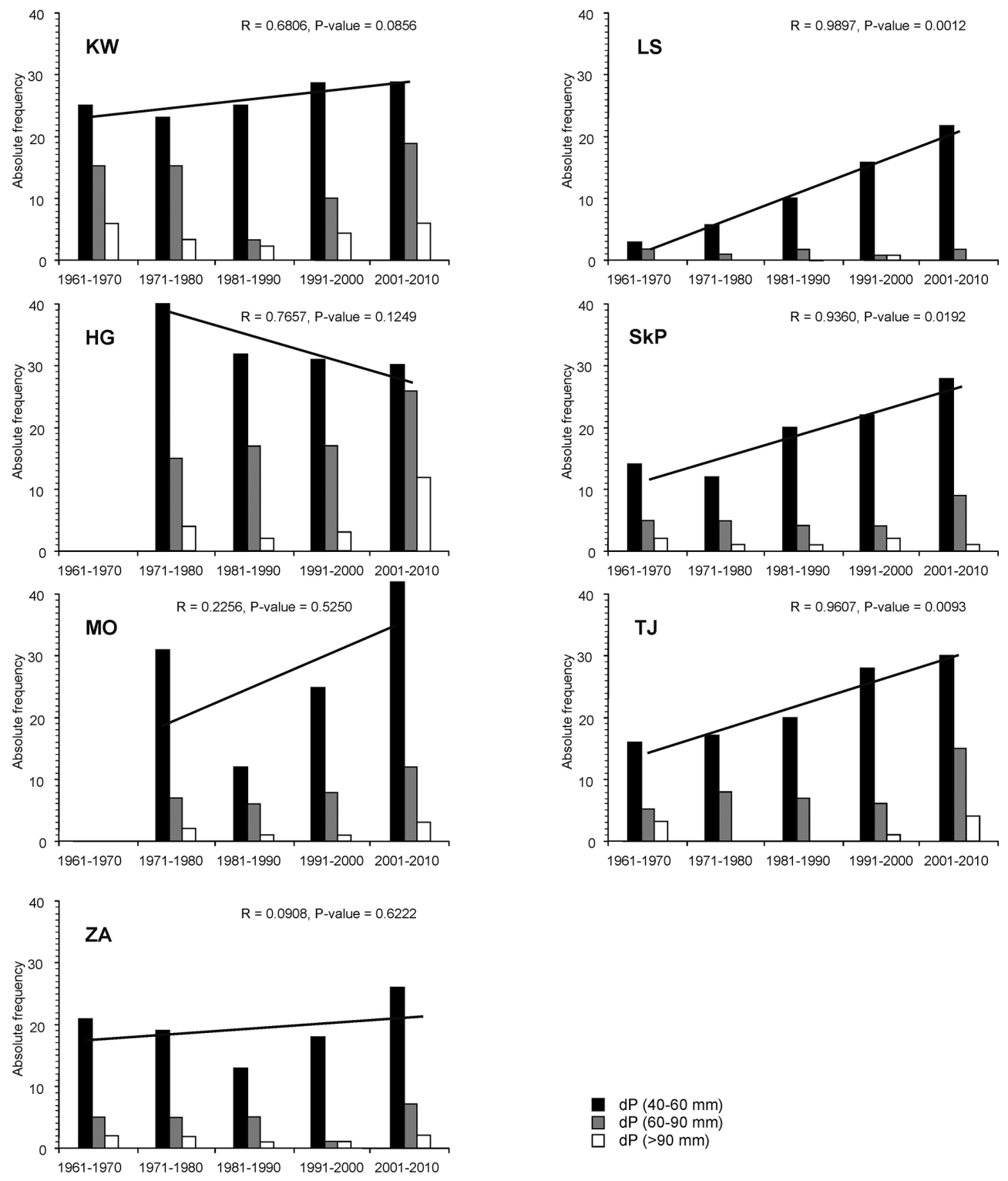

Fig. 4. Absolute frequency of extreme and potentially dangerous daily rainfall in warm seasons (May to October) at the precipitation stations in the High Tatra Mountains; the lines and associated statistics represent daily rainfall $40-60 \mathrm{~mm}$

Source: LS, SkP, TJ - after Bičárová, Holko, 2013; other stations - completed by authors. 


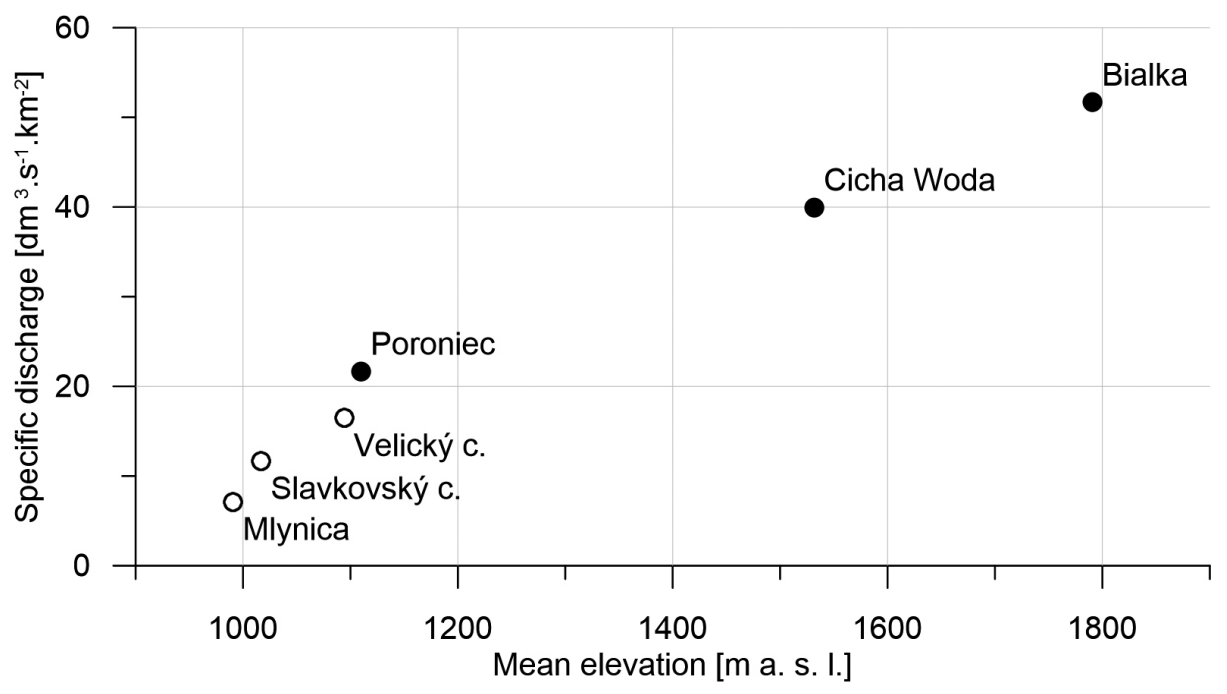

Fig. 5. Catchment mean elevation and annual specific discharge for the leeward and windward sides of the High Tatra Mountains, with the exception of Poroniec the data represent the period 1963-2010 (see Tab. 2)

\section{Asymmetry}

The highest ranges, the highest observed daily runoff $(76.2-197 \mathrm{~mm})$ and the highest number of outliers have been observed in catchments on the northern slope, i.e. Białka, Poroniec, Cicha Woda (Fig. 4; Tab. 5, col. 8). The highest range, the highest observed daily runoff $(47.7 \mathrm{~mm})$, and the highest number of outliers on the southern slope occur in the Velický creek catchment (Fig. 6; Tab. 5, col. 8). Daily runoff in the catchment having the lowest mean altitude (Mlynica, $991 \mathrm{~m}$ a.s.l.) has the smallest range. Up to $25 \%$ of the daily river runoff in the studied catchments does not exceed $1 \mathrm{~mm}$ except Białka and Cicha Woda (Tab. 5, col. 2).

The highest values of all frequency distribution statistics related to daily runoff are found in northern catchments (Białka, Cicha Woda, Poroniec). The median and mean values range between $1.2 \mathrm{~mm}-2.5 \mathrm{~mm}$ and $1.9 \mathrm{~mm}-4.3 \mathrm{~mm}$ respectively, while on the southern slopes they range between $0.4-1.0 \mathrm{~mm}$ and $0.6-1.4 \mathrm{~mm}$ (Tab. 5, col. 3, 4). The smallest values of daily runoff distribution parameters are associated with the Mlynica catchment while the highest values mostly refer to the Białka catchment. 


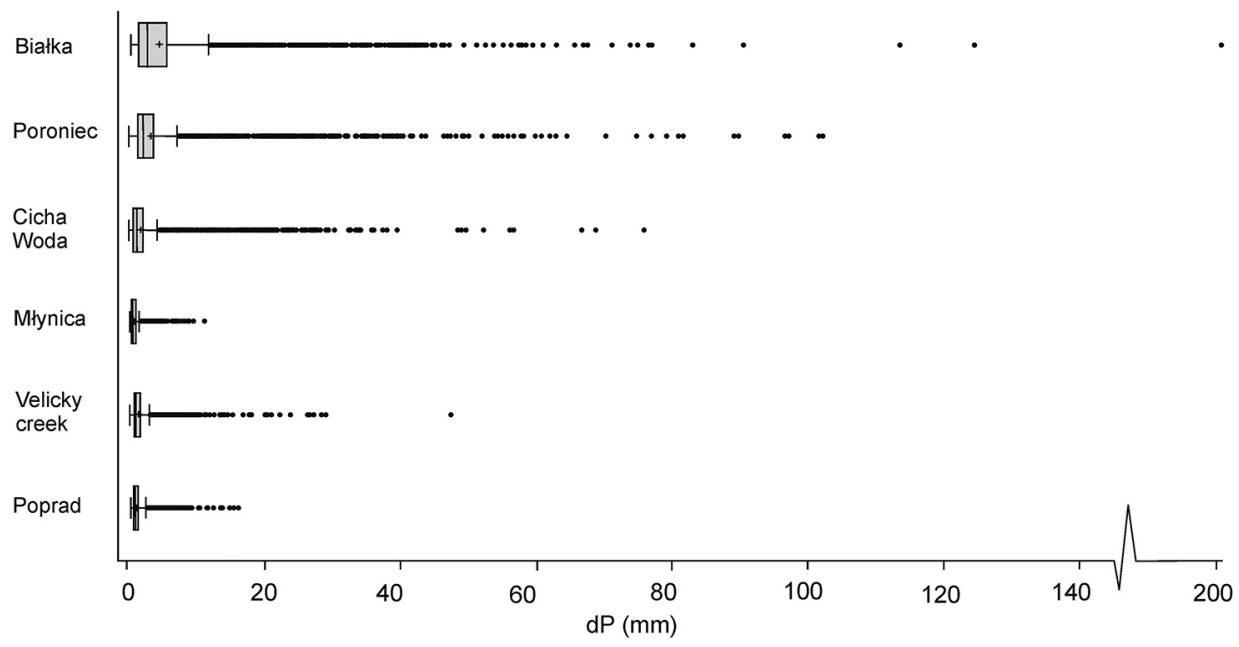

Fig. 6. Box-Whiskers plot of daily river runoff in the catchments in hydrological years 1970-2010 (Białka, Poroniec, Cicha Woda, Mlynica, Velický creek) and 1970-2009 (Poprad) Source: Mlynica, Velický creek, Poprad - after Bičárová, Holko 2013; other catchments - completed by authors.

Table 5. Summary statistics of daily runoff $(\mathrm{mm})$ in the High Tatra Mountains catchments in the periods 1970-2010 (Białka, Poroniec, Cicha Woda, Mlynica, Velický creek) and 1970-2009 (Poprad)

\begin{tabular}{|l|c|c|c|c|c|c|c|}
\hline \multicolumn{1}{|c|}{ Catchment } & $q 1$ & Median & Mean & $q 3$ & $95 p$ & $99 p$ & Maximum \\
\hline \multicolumn{1}{|c|}{1} & 2 & 3 & 4 & 5 & 6 & 7 & 8 \\
\hline Białka & 1.2 & 2.5 & 4.3 & 5.5 & 13.5 & 24.4 & 197 \\
\hline Poroniec & 0.7 & 1.2 & 1.9 & 2.1 & 5,2 & 11.5 & 76.2 \\
\hline Cicha Woda & 1.4 & 2.2 & 3.3 & 3.7 & 8.5 & 23.1 & 102.4 \\
\hline Mlynica & 0.2 & 0.4 & 0.6 & 0.7 & 1.7 & 3.3 & 10.9 \\
\hline Velický creek & 0.7 & 1.0 & 1.4 & 1.6 & 3.5 & 6.5 & 47.7 \\
\hline Poprad & 0.6 & 0.8 & 1.1 & 1.3 & 2.6 & 4.5 & 16.0 \\
\hline
\end{tabular}

Source: Mlynica, Velický creek, Poprad - after Bičárová, Holko 2013; other catchments - completed by authors. 


\section{Temporal variability of flows in the warm season of a year}

There are considerable differences in the number of days with extremely low flows, small floods and large floods among the catchments and decades. A decrease of duration of extremely low flows in the last decade (2001-2010) was observed in four of the six catchments (Tab. 6, col. 3). On the contrary, a significant increase occured in the Mlynica and Cicha Woda catchments in the same decade. The number of small floods in the Poroniec, Mlynica, Velický creek and the Poprad catchments increased in the decade 2001-2010 in comparison with the previous two decades (Tab. 6, col. 4). There were no large floods in the Cicha Woda, Mlynica and Velický creek catchments in the decades 1971-1980 and 2001-2010, in Poprad catchment in the decades 1971-1980 and 1981-1990, and in the Białka and Poroniec catchments in the decades 1981-1990 and 2001-2010, respectively. Tab. 6 reveals an apparent significant increase of the number of large floods in the Białka, Cicha Woda, Mlynica and Velický creek catchments in the 2001-2010 (Tab. 6, col. 5) compared to the previous decade. It could be caused by the extremely wet year of 2010 which is indicated also by the fact that such an increase was not observed in the Poprad catchment which did not have the data in 2010 (the gauge was destroyed by the flood). The highest total number of days with extremely low flows for the entire period 1971-2010 occurred in the Białka catchment (1590). However, this catchment never had the highest number of days with extremely low flows in individual decades (Tab. 6, col. 3).

\section{Discussion and conclusions}

The study presents one of the first comparisons of measured precipitation and runoff covering the entire territory of the transboundary High Tatra Mountains. An increase in the number of small floods in three catchments on the leeward and one catchment on the windwardside of the High Tatra Mountains in the decade 2001-2010 compared to the decade 1991-2000 was found. An increase in the number of large floods was found in the same decade in two catchments on the leeward and two catchment on windward sides of the High Tatra Mountains. It is well documented that runoff response of the small high mountain catchments in the warm period of a year depends in particular on the amount of precipitation (e.g. Kostka, Holko 2003). Thus, the increase in the above mentioned flow characteristics can be associated with a significant increase in the number of days with daily precipitation 40-60 $\mathrm{mm}$ and a more frequent occurrence of the long-term wet periods in the decades 1991-2000 and 2001-2010.

It should be noted that extreme low flows, small and large floods in the investigated catchments in particular decades exhibit significant individuality. 
Table 6. Numbers of days with extremely low flows and the numbers of small and large floods in the High Tatra Mountains catchments

\begin{tabular}{|c|c|c|c|c|}
\hline Catchment & Decade & Extremely low flows & Small floods & Large floods \\
\hline 1 & 2 & 3 & 4 & 5 \\
\hline \multirow{4}{*}{ Białka } & $1971-1980$ & 493 & 168 & 23 \\
\hline & 1981-1990 & 496 & 66 & 0 \\
\hline & 1991-2000 & 362 & 297 & 10 \\
\hline & 2001-2010 & 239 & 159 & 92 \\
\hline \multirow{4}{*}{ Poroniec } & 1971-1980 & 326 & 162 & 29 \\
\hline & 1981-1990 & 367 & 124 & 71 \\
\hline & 1991-2000 & 415 & 121 & 9 \\
\hline & 2001-2010 & 359 & 192 & 0 \\
\hline \multirow{4}{*}{ Cicha Woda } & 1971-1980 & 636 & 49 & 40 \\
\hline & 1981-1990 & 395 & 307 & 0 \\
\hline & $1991-2000$ & 133 & 193 & 0 \\
\hline & 2001-2010 & 307 & 152 & 76 \\
\hline \multirow{4}{*}{ Mlynica } & 1971-1980 & 283 & 166 & 80 \\
\hline & 1981-1990 & 360 & 229 & 0 \\
\hline & $1991-2000$ & 282 & 141 & 0 \\
\hline & 2001-2010 & 456 & 179 & 27 \\
\hline \multirow{4}{*}{ Velický creek } & 1971-1980 & 311 & 109 & 28 \\
\hline & 1981-1990 & 625 & 90 & 0 \\
\hline & $1991-2000$ & 360 & 144 & 0 \\
\hline & 2001-2010 & 173 & 234 & 122 \\
\hline \multirow{4}{*}{ Poprad } & $1971-1980$ & 287 & 195 & 0 \\
\hline & 1981-1990 & 523 & 134 & 0 \\
\hline & $1991-2000$ & 323 & 51 & 38 \\
\hline & $2001-2009$ & 271 & 176 & 33 \\
\hline
\end{tabular}

Source: Mlynica, Velický creek, Poprad - after Bičárová, Holko 2013; other catchments - completed by authors. 
The individuality of runoff regime in the Tatra Mountains was already highlighted by Pociask-Karteczka et al. (2010) who also found an increase of large flood events in the decade 2001-2010.

Precipitation data revealed extreme outliers especially on the windward slope of the Tatra Mountains. For instance, the Morskie Oko station had the longest period without precipitation in 1991-2000 (75 days) and also the highest number (44) of long-term wet periods in 1971-1980. These cases would deserve special attention in future studies.

Considerable differences in precipitation and runoff in the High Tatra Mountains seem to reflect mainly the influence of windward and leeward positions. This phenomenon was already described for precipitation in the Slovak part of the Tatra Mountains e.g. by Molnár and Pacl (1988). Pacl (1973) also described the differences in seasonality of runoff and specific runoff on the northern and southern sides of the Tatra Mountains. The prevailing western and north-western atmospheric circulation results in high precipitation on the northern slopes of the mountains. The atmospheric circulation in this part of Europe is controlled by the North Atlantic Oscillation (NAO). A number of studies confirmed the influence of NAO and other large-scale weather phenomena on hydrological cycle (e.g. Pociask-Karteczka 2006; Pekárová, Pekár 2007; Wrzesiński 2008). Although it is difficult to establish unequivocally the influence of the NAO on mountain areas, further research in the Tatra Mountains could address the issue of spatial differences in the NAO impact demonstrated on the European scale by Wrzesiński and Paluszkiewicz (2011).

\section{Acknowledgement}

This work was supported by research projects VEGA 2/0053/14, 2/0055/15 and APVV 15-0497.

\section{References}

Alexandersson A., 1986, A homogeneity test applied to precipitation data, Journal of Climatology, 6, 661-675.

Barnett T., Adam J., Lettenmaier D., 2005, Potential impacts of a warming climate on water availability in snow-dominated regions, Nature, 438, 303-309.

Bičárová S., Holko L., 2013, Changes of characteristics of daily precipitation and runoff in the High Tatra Mountains, Slovakia over the last fifty years, Contributions to Geophysics and Geodesy, 43 (2), 157-177.

Blöschl G., Montanari A., 2010, Climate change impacts - throwing the dice?, Hydrological Processes, 24, 374-381. 
Bokwa A., Wypych A., Ustrnul Z., 2013, Climate changes in the Vertical Zones of the Polish Carpathians in the Last 50 Years, [in] J. Kozak, K. Ostapowicz, A. Bytnerowicz, B. Wyżga (eds.), The Carpathians: Integrating Nature and Society Towards Sustainability, Environmental Science and Engineering, Environmental Science, Springer-Verlag Berlin-Heidelberg, 89-109.

Cebulak E., Faško P., Lapin M., Štastný P., 2000, Extreme precipitation events in the Western Carpathians, Prace Geograficzne, 108, 117-124.

Faško P., Lapin M., Štastný P., Vivoda J., 2000, Maximum daily sums of precipitation in Slovakia in the second half of the 20 th century, Prace Geograficzne, 108, 131-138.

Fleischer P., Pichler V., Fleischer P. Jr, Holko L., Máliš F., Gömöryová E., Cudlín P., Holeksa J., Michalová Z., Homolová Z., Škvarenina J., Střelcová K., Hlaváč P., 2017, Forest ecosystem services affected by natural disturbances, climate and land-use changes in the Tatra Mountains, Climate Research Special: Resilience in Sensitive mountain Forest ecosystems under environmental change (in press).

Halmová D., Pekárová P., 2011, Statistical evaluation of the extreme flood and drought changes in the Bel'a river basin. Influence of Anthropogenic Activities on Water Regime of Lowland Territory, Physics of Soil Water, Vinianske jazero Lake, May, 17th-19th, 2011, Slovak Republic.

Holko L., Parajka J., Majerčáková O., Faško P., 2001, Hydrological balance of selected catchments in the Tatra Mountains region in hydrological years 1989-1998, Journal of Hydrology and Hydromechanics, 49, 3-4, 200-222.

Huber U.M., Bugmann H., Reasoner M. (eds.), 2005, Global change and mountain regions: An overview of current knowledge, Springer, Dordrecht.

Kasina M., Pociask-Karteczka J., Nieckarz Z., 2006-2007, Tendencies of high flows in the Dunajec River basin in the second half of the $X X c$., Folia Geographica, Series Geographica-Physica, 37-38, 3-33.

Kostka Z., Holko L., 2003, Analysis of rainfall-runoff events in a mountain catchment, Technical Documents in Hydrology, Unesco, Paris, 19-25.

Kotarba A., 1992, Natural Environment and Landform Dynamics of the Tatra Mountains, Mountain Research and Development, 12, 2, 105-129.

Kundzewicz Z.W. (ed.), 2012, Changes in flood risk in Europe, IAHS Spec. Publication, 10.

Kundzewicz Z.W., Graczyk D., Maurer T., Przymusińska I., Radziejewski M., Svensson C., Szwed M., 2004, Detection of change in world-wide hydrological time-series of maximum annual flow WCASP-64, WMO, Geneva.

Kundzewicz Z.W., Graczyk D., Maurer T., Przymusińska I., Radziejewski M., Svensson C., Szwed M., 2005, Trend detection in river flow time-series: 1 annual maximum flow, Hydrological Sciences Journal, 50, 797-810.

Lukniš M., 1973, Reliéf Vysokých Tatier a ich predpolia, SAV, Bratislava. 
Łupikasza E., Niedźwiedź T., Pinskwar I., Ruiz-VillanuevaV., Kundzewicz Z.W., 2016, Observed Changes in Air Temperature and Precipitation and Relationship between them, in the Upper Vistula Basin, [in] Z.W. Kundzewicz, M. Stoffel, T. Niedźwiedź, B. Wyżga (eds.), The Upper Flood Risk in the Upper Vistula Basin, GeoPlanet: Earth and Planetary Sciences, Springer, 155-188.

Mačutek J., Zahradníček P., Bičarová S., Štěpánek P., 2011, Homogenisation of precipitation data at peak mountain site Lomnický štít (1961-2010), [in:] B. Šiška, M. Hauptvogl, M. Eliášová (eds.), Bioclimate - source and limit of social development, Conference proceedings, Slovak Agricultural University, Nitra.

Maronna T., Yohai V.J., 1978, A bivariate test for the detection of a systematic change in mean, Journal of the American Statistical Association, 73, 640-645.

Melo M., Lapin M., Kapolková H., Pecho J., Kružicová A., 2013, Climate Trends in the Slovak Part of the Carpathians [in:] J. Kozak, K. Ostapowicz, A. Bytnerowicz, B. Wyżga (eds.), The Carpathians: Integrating Nature and Society Towards Sustainability, Environmental Science and Engineering, Environmental Science, Springer-Verlag, Berlin-Heidelberg, 131-150.

Molnár L., Pacl J., 1988, The hydrological characteristics of the High Tatra region: Hydrology of Mountainous Areas, Czechosovakia, Introductory paper, Institute of Hydrology and Hydraulics, Slovak Academy of Sciences, Bratislava.

Mudelsee M., Börngen M., Tetzlaff G., Grünewald U., 2003, No upward trends in the occurrence of extreme floods in central Europe, Nature, 425, www.nature.com/nature.

Niedźwiedź T., 2003, Extreme precipitation events on the northern side of the Tatra Mountains, Geographia Polonica, 76, 2, 15-23.

Pacl J., 1973, Hydrológia Tatranského národného parku, Zborník prác o Tatranskom Národnom Parku, 15, 181-238.

Parajka J.G., Kohnová S., Bálint G., Barbuc M., Borga M., Claps P., Cheval S., Dumitrescu A., Gaume E., Hlavčová K., Merz R., Pfaundler M., Stancalie G., Szolgay J., Blöschl G., 2010, Seasonal characteristics of flood regimes across the Alpine-Carpathian range, Journal of Hydrology, 394 (1-2), 78-89.

Pekárová P., Pekár J., 2007, Teleconnections of Inter-Annual Streamflow Fluctuation in Slovakia with Antarctic Oscillation, North Atlantic Oscillation, Southern Oscillation and Quasi-Biennial Oscillation Phenomena, Advances in Atmospheric Sciences, 24, 4, 655-663.

Pociask-Karteczka J., 2006, River hydrology and the North Atlantic Oscillation - a general review, Ambio, 35(6), 312-314.

Pociask-Karteczka J., Baścik M., Nieckarz Z., 2010, Zróśnicowanie præestræenne i smienność odpływu ze zlewni tatrzańskich, [in:] A. Kotarba (ed.), Przyroda Tatrzańskiego Parku Narodowego a Cistowiek. Nauka a zarzqdzanie obszarem Tatr i ich otoczeniem, T. 1: Nauki o Ziemi, Tatrzański Park Narodowy, Polskie Towarzystwo Przyjaciół Nauk o Ziemi, Oddz. Kraków, Zakopane, 123-130. 
Pribullová A., Chmelík M., Pecho J., 2013, Air Temperature Variability in the High Tatra Mountains, [in:] J. Kozak, K. Ostapowicz, A. Bytnerowicz, B. Wyżga (eds.), The Carpathians: Integrating Nature and Society Towards Sustainability, Environmental Science and Engineering, Environmental Science, Springer-Verlag, Berlin-Heidelberg, 111-130.

Ruiz-Villanueva V., Wyżga B., Kundzewicz Z.W., Niedźwiedź T., Łupikasza E., Stoffel M., 2016, Variability of Flood Frequency and Magnitude During the Late 20th and Early 21st Centuries in the Northern Foreland of the Tatra Mountains, [in:] Z.W. Kundzewicz, M. Stoffel, T. Niedźwiedź, B. Wyżga (eds.), The Upper Flood Risk in the Upper Vistula Basin, GeoPlanet: Earth and Planetary Sciences, Springer, Berlin-Heidelberg, 231-256.

Štěpánek P., 2010, ProClimDB - software for processing climatological datasets, CHMI, regional office Brno, http://www.climahom.eu/ProcData.html.

The Nature Conservancy, 2009, Indicators of Hydrologic Alteration Version 7.1 User's Manual.

Ustrnul Z., Czekierda D., 2009, Atlas ekstremalnych wjawisk meteorologicznych oraz sytuacji synoptycznych w Polsce, IMGW, Warszawa.

Wrzesiński D., 2008, Typology of spatial patterns seasonality in European rivers flow regime, Quaestiones Geographicae, 27A/1, 87-98.

Wrzesiński D., Paluszkiewicz R., 2011, Spatial differences in the impact of the North Atlantic Oscillation on the flow of rivers in Europe, Hydrology Research, 42 (1), 30-39.

http://pocasi.chmi.cz/en

https://www.ncdc.noaa.gov/

\author{
Marek Górnik \\ Jagiellonian University \\ Institute of Geography and Spatial Management \\ ul. Gronostajowa 7, 30-387 Kraków, Poland \\ marek4891@poc*ta.fm \\ Joanna Pociask-Karteczka \\ Jagiellonian University \\ Institute of Geography and Spatial Management \\ ul. Gronostajowa 7, 30-387 Kraków, Poland \\ joanna.pociask-karteczka@uj.edu.pl \\ Ladislav Holko \\ Institute of Hydrology of the Slovak Academy of Sciences \\ Experimental Hydrological Base \\ Ondrašovská 16, 031-05 Liptovsky Mikuláš, Slovak Republic \\ ladislav.holko@savba.sk \\ Svetlana Bičárová \\ Earth Science Institute of the Slovak Academy of Sciences \\ Meteorological Observatory Stará Lesná \\ 059-60 Tatranská Lomnica, Slovak Republic \\ bicarova@ta3.sk
}

